\title{
HOW TO SPLIT THE HERITAGE WHEN \\ INVENTING A NATION. GERMANY'S \\ POLITICAL AND MUSICAL DIVISION.
}

\section{MARIE-AGNES DITTRICH}

\begin{abstract}
After the end of the old Empire in the Napoleonic Age, the states which are now Austria and Germany have separated gradually. But due to the rivalry which had emerged between Prussia and Austria in the decades before the new German Empire excluded Austria, the concept of "Germany" had to be redefined by differentiation not only from France, but from Austria too. Promoting the idea of an inherently "German" culture without admitting the superiority of practically all European cultural centres and especially of Vienna's rich cultural and musical heritage required a redrawing of the map of Europe's musical memory with the help of great dividers like religion or gender roles. Germans liked to believe that they were, as predominantly Protestants, more intellectual, progressive, and masculine, as opposed to the decadent, traditionalist Catholics in Austria. This "othering" of Austria affected the reception of composers like Beethoven, whom Prussia appropriated as German, or Schubert as typically Austrian. Similar differences were constructed with the shifting relationships between Germany and Austria after the WWI and after National Socialism, and when Germany itself was divided once more.
\end{abstract}

Key words: Germany; Austria; othering; ideology of music; gender; $19^{\text {th }}$ century.

The topic of this essay is personal. ${ }^{1}$ Born and raised in Germany, I became an Austrian citizen in 1993 and ever since then have been fascinated by the complex relationship between my two countries which have had been united within one empire for centuries.

The history of a German-nation state begins during the Napoleonic wars when the Emperor Franz II (1768-1835) named himself Emperor (Franz I) of Austria (1804) and, two years later, abdicated as Emperor of the Holy Roman Empire of the German Nation ${ }^{2}$, which was then dissolved. After Napoleon's defeat many different states, principalities, and free cities within the former empire founded the Confederation (Deutscher Bund, 1815-1866). Since it was the successor of the old Holy Roman Empire, it kept its coat of arms: a black double-headed eagle with red beaks and red talons on a golden background. The democratic

1 My contribution at the conference was a commented slide show, and this paper does not attempt to change the style of the verbal presentation. A reproduction of the many images shown would not be feasible, but nearly all of them can easily be found on the web. Links are only provided when the search keywords are not entirely clear.

2 "Heiliges Römisches Reich Deutscher Nation". 
movement of the revolution of 1848 chose these colours for a flag, which much later, after the Second World War, would be used again by the Federal Republic of Germany. Austria was the confederation's Presiding power (Präsidialmacht) and Vienna, the old imperial residence, was like a capital.

But Austria had a rival within the Confederation, the fairly new kingdom of Prussia, which had competed with Austria at least since the 18th century. Many new conflicts between these two states and their respective allies (for example, how to divide a province that Austria and Prussia, once united, had taken from Denmark in the war of 1864) erupted into war in 1866 . The winners were Prussia and his allies which then founded their own North German Confederation (Norddeutscher Bund) dominated by Prussia. Its capital was Berlin. Austria, on the other hand, had to give greater independence to some of its parts. Its official name since 1867 is Austro-Hungarian Monarchy (Österreichisch-Ungarische Monarchie).

When Prussia declared war on France in 1870, some of Austria's former allies fought on Prussia's side. After the defeat of France in 1871, the princes of these states made the Prussian king their emperor (Wilhelm I, 1797-1888), tactfully in the castle of Versailles. Paintings by Anton von Werner (1843-1915), at that time a very famous painter of historical scenes and so important to Prussian propaganda that he was said to be the artistic part of the great Prussian arsenal ${ }^{3}$ (Khaynach, 1893, 28.), show the moment of the emperor's proclamation. ${ }^{4}$

Thus emerged the second German Empire (Deutsches Reich, 1871-1918) which was dominated by Prussia and therefore continued to use Prussia's insignia, a one-headed black eagle and the black, white and red flag. But this new Empire also appropriated symbols that before had belonged to all Germans, Austrians included.

The separation between the two German states is shown by representations of "Germania", the personification of Germany which was, depending on the political context, an equivalent or a rival of the French "Marianne". A painting from 1848 (Veit?, 1848), attributed to Philipp Veit (1793-1877) and based on his Germania from 1836 (Veit, 1836), shows Germania with a sword, but with olive branches signifying peace in one hand and, at her feet, the chains of oppression by the princes, now broken. She wears the old Empire's coat of arms on her chest to indicate that the democratic revolutionaries wanted not to destroy the German Confederation, but to liberate it from the traditional despotism.

After the failed revolution of 1848, conflicts with France and nationalistic sentiments increased. A painting (1860) by Lorenz Clasen (1812-1899) shows

3 “die künstlerische Seite des großen preußischen Waffenlagers".

4 Werner painted three versions, to be found with the keyword "Kaiserproklamation", cf Bartmann, 1993. 
Germania auf der Wacht am Rhein (Germania guarding the Rhine) as a warrior, ready to defend Germany against France. The title of the painting refers to a very popular song that praised the fact that the river Rhine - that is, the most important part of the frontier between the two countries - would always be watched over, defended and thus defined as a "German" river. (Cepl-Kaufmann and Johanning, 2003). The relationship with France had indeed been uneasy at least since the wars of Louis XIV. Clasen's Germania looks, ready for battle, across the river to the left, towards the west and towards France. She holds a sword, but now no longer with an olive branch. But she still uses the empire's coat of arms, and at her side she has kept its insignia. Thus, she represents once again Germany which included Austria.

Three wars later, a flag of the Combattanten-Verein Ehrenfeld (Association of Combatants) $)^{5}$ uses Clasen's painting. By now, Germania's accoutrements have changed. Although she has kept the old Empire's insignia, thus declaring herself its successor, her coat of arms shows the Prussian one-headed eagle of the New German Empire. And, with the help of God - at least according to the inscription which includes the words "Gott war mit uns" (God was with us) - Germania has fought and won three wars, according to the dates in the medallions around her: two against foreign states, Denmark (1864) and France (1870/1871), but also one against Austria (1866). The reference to the victory of 1866 indicated that Austria was no longer regarded as part of Germany. For Austrians the lost war was a traumatic experience and has never been forgotten. The location of the decisive battle at Königgrätz near Prague is still well remembered in Austria: whenever Austria wins an important sports match against Germany, newspapers are prone to talk of Revenge for Königgrätz (Rache für Königgrätz) ${ }^{6}$. In Austria, the name for a North German is Piefke. This is not supposed to be nice. Johann Gottfried Piefke (1815-1884) was a Prussian composer who became famous for a March he was said to have composed on the very battlefield of Königgrätz. This Königgrätzer Marsch is particularly offensive because its trio quotes the 18thcentury-Hohenfriedberger Marsch which celebrated a Prussian victory over Austria (and allies) in a battle of 1745 . The message is clear: whenever Austria fights against Prussia, Prussia wins. The Königgrätzer Marsch enjoys great popularity even nowadays (Dittrich, 2011), especially with extreme-right nationalists (not a few of whom are Austrians longing for a reunification with Germany).

For Prussia, the victory over and separation from Austria fit into a narrative of success, according to which ancient Rome, decadent, had to be succeeded by the first Holy Roman Empire of the German Nation, which in its turn had to give way to the German Empire: according to Hegel (1770-1831) 7 , history is determined

5 I could not find an image of this flag online; cf. Plessen, 1996, 34.

6 It is interesting how many and what kind of results a search of this phrase finds online.

7 For an introduction to Hegel as a Historian see Beiser, 1993, 270-300. 
by a "Fortgang zum Besseren" (Hegel, 1961, 105), which is a progress towards the better. And, according to Hegel, the Protestant states were more progressive, because Catholicism was opposed to freedom, enlightenment and progress of thought. (Hegel, 1961, 590-601) Whereas Hegel's philosophy of progress was embraced by Prussia, Austria was said to be as decadent as the old empire, since it was still based on Gottfried Wilhelm Leibniz' (1646-1716) philosophy of a preestablished harmony, clung to obsolescent traditions and impeded scholarship and science. (Boisits, 2004, 129-136).

For decades, "Germany" had been defined as a cultural entity which included what we now call Austria. The emerging Germany of the $19^{\text {th }}$ century, a NationState without Austria, had hardly any cultural identity. Promoting the idea of an exclusively "German" culture against the factual superiority of practically all European cultural centres, and especially against Austria's rich cultural heritage, required a reshaping of Europe's memory.

Thus, Prussia's cultural significance needed to be vastly exaggerated. The $18^{\text {th }}$ century king Friedrich II (in Germany called the Great, 1712-1786), was praised as a patron of the arts because he was supposed to have suggested the Royal theme for Johann Sebastian Bach's (1685-1750) Musikalisches Opfer (Musical Offering, 1747), and because he composed and played the flute. Adolf von Menzel's (1815-1905) painting Flötenkonzert Friedrichs des Großen in Sanssouci (The Flute Concert of Frederick the Great at Sanssouci, 1850-52) showing him playing a concert (or even one of his own concertos?) ${ }^{8}$, was given a prominent place in the most important art museum in Berlin of that time ${ }^{9}$. But neither such meagre and isolated incidents nor the fact that most German philosophers and poets were Protestants could even begin to equal the rich culture of imperial Vienna. And thus the newly defined Germans devaluated their rivals by insinuating that Austria was not worthy of its great heritage. ${ }^{10}$

Old hostilities were revived, and since Prussia's Protestantism dominated in the new Germany, religion was used as the great divider. Historians now speak of a German Proto-Nationalism which arose during the Reformation but profited from anti-Roman propaganda that was widespread even earlier - and which was also, and significantly, very gendered. For example, an engraving by Albrecht Dürer (1471-1528) shows Das Babylonische Weib (The Whore of Babylon, 1496/97) venerated by, among others, a monk. (Allard, 2008, 147f) There were many illustrations either of the Babylonian Whore wearing the pope's tiara, or of a monster - a female figure with a donkey's head, supposedly

8 The German term "Konzert" means both "concert" and "concerto".

9 Today it is called Alte Nationalgalerie.

${ }^{10}$ Since I have been interested in the "German" interpretation of Franz Schubert, much of the last part of this paper is based on previous publications, e.g. Dittrich, 2001, 3-21. 
found in Rome and used as Papstesel (pope-donkey) in Lutheran propaganda (Anon, 2018). Clichés about Protestants and Catholics abounded and were also gendered: The Protestants, reading the bible and supposedly forming their own relationship with God, liked to think of themselves as intellectually more independent and rational, and of Catholics, on the other hand, as emotionally dependent on authorities and superstitious traditions. In the $19^{\text {th }}$ century even many Catholics believed in these differences, blaming the lack of a culture of discourse on the Counter-Reformation. A very famous drama by the Austrian poet Franz Grillparzer (1791-1872), König Ottokars Glück und Ende (1825), contains a description of Austria. (act III, scene 3) School children learned it by heart well into the $20^{\text {th }}$ century. Austria is portrayed as a country of great natural beauty. Although Austrians are less intellectual than the Germans and less capable of controversy, they are more pious. And, significantly: Austria is like a youngster and Germany is a man. Grillparzer himself was criticised for a supposedly typically Austrian lack of dramatic force. (Suchy, 1965, 35f) $19^{\text {th }}$ century clichés about Germany and Austria are full of binary and very often gendered oppositions for the purpose of "othering" Austria. One finds them everywhere, even in books and journals about music.

Among the many publications, the one by Richard Wagner (1814-1883) may as well have been the nastiest. His booklet Beethoven was written for $100^{\text {th }}$ anniversary of Beethoven's birth in 1870 . Beethoven has been much venerated in Berlin already since the 1820s (Bauer, 1992) and the Prussian state profited by the fact that he had been born in Bonn, which had become a Prussian province after the Napoleonic wars. But centenary of Beethoven's birth coincided with Germany's attack on France, and Wagner's booklet was a pure German nationalist propaganda. It promoted the idea, very popular at the time, that German culture was deeper felt and that Germany was ultimately superior to both France and Austria. Austria was (like France) rotten to the core, ruined by Catholics and the nobility, it lacked intellectual freedom, never appreciated its artists, and let Mozart die in misery. (Wagner, 1873, 79-151) Beethoven, although raised a Catholic and although he lived in Vienna, was considered as great because he had been inspired by German Protestantism. What he felt about Haydn is "like (what) a true man (feels) about a childish geriatric man." ${ }^{11}$ (Wagner, 1873, 80) Only in his youth he could have accepted Haydn as his teacher, but for Beethoven the man, there was only one leader (Führer): the great German Johann Sebastian Bach. (Wagner, 1873. 115 f) The idea that only German composers could create significant works continued to thrive in the $20^{\text {th }}$ century. (Potter, 1998) Even Austrians subscribed to those ideas. Tragically, Arnold Schoenberg (18741951), born into an Austrian Jewish family, was eager to be part of this assumed

11 ”Es scheint, er fühlte sich Haydn verwandt wie der geborene Mann dem kindlichen Greise." 
"German" tradition which was believed to connect Bach, Beethoven (17701827) and Brahms (1833-1897). ${ }^{12}$

The German Empire defined itself as a warrior nation; founded during a war with France, and proclaimed at Versailles (1871) it also made sure that nobody would ever forget its triumphal origins. Its social structure and mentality - although the latter allegedly grounded in deep emotions - were defined by militarism. (Wette, 2008) In this context and under the influence of Hegel's philosophy, much of Beethoven's music was felt to be heroic. (Burnham, 1995) It was even said that the German chancellor Otto von Bismarck (1815-1898) had felt compelled to attack Austria in 1866 after having listened to Beethoven's Fifth Symphony. This seems to be a myth, but it is significant that people actually believed it. (Dennis, 1996, 36-48)

Even Beethoven's monument in Vienna (1880) by Caspar von Zumbusch (1830-1915) interprets him this way. Beethoven looks grimly determined, while Prometheus at the monument's base stands as a symbol of his titanic struggle against fate. Although its political background is now mostly forgotten, this image of Beethoven remains in the heads of many conductors and causes misinterpretations. Just think of one of his most heroic works - how often does one hear the first theme of the Eroica played like the waltz that it is? (Voss, 2005, 103)

According to the later $19^{\text {th }}$ century narrative, Schubert compared to Beethoven seemed "like a child playing among giants"13 (La Mara, 1868, 113). Schubert's Vienna monument (1872) by Carl Kundmann (1838-1919) is situated in a park, because Schubert, according to the long dedication poem (Neue Zeitschrift für Musik, 1972, 254f), composed as easily as flowers spring from the ground. For Grove (1820-1900), Schubert's music flowed through him from heaven (apparently he only needed to hold his pen). Grove's comparison of Beethoven and Schubert shares the gendered interpretation of his contemporaries: “(...) compared with Beethoven, Schubert is as a woman (compared) to a man. For it must be confessed that one's attitude towards him is almost always that of sympathy, attraction, and love, rarely that of embarrassment or fear (...) and how different is this (...) from the strong, fierce, merciless coercion, with which Beethoven forces you along, and bows and bends you to his will." (Grove, 1883, 364) Binary opposition was also used in the Brahms-Bruckner controversy. The association of Brahms (a Protestant intellectual from a big city) and Bruckner (a Catholic country bumpkin from Upper Austria) was clearly connected to the underlying German-Austrian conflict.

\footnotetext{
${ }^{12}$ For a (much criticized) rendering of a German-centered music history cf. Eggebrecht, 1991.

13 "wie ein Kind, das unter Riesen spielt".
} 
But in spite of all the Prussian triumphalism, for Austrians the lost war of 1866 was not all bad. The loss of prestige of the military and the nobility became an advantage for the middle-class. For them, the unheroic Schubert was a symbol of identification, and his Vienna monument was a political statement of emancipation and liberty (as the dedication poem for the Schubert monument explicitly stated).

Nevertheless, many Austrians suffered from an inferiority complex and longed to be reunited with Germany. As we all know, their wish was granted when Germania looked like the one in Friedrich August von Kaulbach's (18501920) painting with the title Deutschland August 1914: very aggressive, behind her a flaming horizon in red and black. After the war, and after the collapse of the Austro-Hungarian Empire, the much reduced new state of Austria was eager to point out its independence from Germany. Music, theatre pieces and films showed a child-like Mozart or an awkward Schubert to prove that Austrians were harmless, if a bit irresponsible, and very different from those masculine and over-organised Germans. (Mayer-Hirzberger, 2008) But, the old longing for political unity and German approval remained popular. A postcard from the 1920s shows a Schubertfeier im Elysium. Forellenquintett (Schubert celebration in Elysium. Trout Quintett): Austrian and German composers playing Schubert's Forellenquintett, while others (even "Germans" like Beethoven and Wagner) listened. And Schoenberg proudly announcing the predominance of German music for the next 100 years $^{14}$ (Rufer, 1959, 26; Gradenwitz, 2000, 21), wanted to be seen as a German, not as a mere Austrian composer. The German Walhalla, a hall of fame planned after the Napoleonic wars, has since been filled with busts of Germans considered the great ones. What a triumph for one Austrian not only to have become Chancellor of Germany but also to celebrate the admission of a fellow Upper Austrian into this place of memory. A famous photograph of Adolf Hitler (1889-1945) shows him standing before the bust of Bruckner in 1937. ${ }^{15}$ One year later, Austria came "heim ins Reich" (home into the Empire), as the Nazi slogan went. The Third Reich, by the way, used the Prussian colours (black, white and red) for its flag.

Millions of deaths later, music was again used to define separate identities. Austrians once more let non-threatening music like Waltzes show their difference from the Germans ${ }^{16}$ and made very clear that they had not been supporters of Nazi Germany, but its first victims. In fact there is a saying, ascribed to different sources, that Austrians managed to convince the world that Beethoven had been an Austrian and Hitler a German.

\footnotetext{
14 "Vorherrschaft der deutschen Musik für die nächsten 100 Jahre".

${ }^{15}$ Search for the key words "hitler walhalla bruckner" - but be warned: you might find it most easily on websites affiliated with neo-Nazis.

16 The film Sound of Music is a very good example.
} 
The Germans, on the other hand, invented the idea of a "Stunde Null" (Zero Hour) in 1945, as if there had been no past, no history, no war, no genocide. Everything was new, also the arts and music, and the Darmstadt festival proclaimed a New Music appropriate to a country without a past. Now we know differently. There were still National-Socialists active in German politics and culture, to an extent that historians now wonder how Germany ever managed to become quite a respectable democracy.

A bit later the heritage needed to be divided again, when Germany was split into two states (1949-1990). To whom did Johann Sebastian Bach belong? On a Bach-conference at Leipzig (1950), West German musicologists claimed Bach as theirs, because he was a devout Lutheran; the East Germans, on the other hand, interpreted him as a crypto-socialist. (Dittrich, 2007) And both German states used the festivities to honour the German Bach's anniversary to demonstrate to the world that they were a Kulturnation ${ }^{17}$, after all, and not the barbarians that they had shown themselves to be.

\section{References}

Allard, S., 2008. Der Mythos Babylon vom 16. bis zum 19. Jahrhundert. In: M. Wullen and G. Schauerte in collaboration with H. Strzoda, eds. Babylon. Mythos und Wahrheit. Katalogband zur Ausstellung "Babylon Mythos". München: Hirmer. 145-167.

Anon, 1996. Flag. [photograph] Reproduced in: Plessen, M. v., Germania aus dem Fundus. In: M. v. Plessen, ed. Marianne und Germania. Frankreich und Deutschland. Zwei Welten - Eine Revue 1789-1889. Katalog zur Ausstellung der 46. Berliner Festwochen Berlin 1996. Berlin: Argon. 31-36.

Anon, 2018. Papstesel. [jpg image] Available at: <https://de.wikipedia.org/ wiki/Papstesel> [Accessed 30 June 2018].

Bartmann, D. ed., 1993. Anton von Werner. Geschichte in Bildern. München: Hirmer.

Bauer, E. E., 1992. Wie Beethoven auf den Sockel kam. Die Entstehung eines mysikalischen Mythos. Stuttgart: Metzler.

Beiser, F., 1993. The Cambridge companion to Hegel. Cambridge: Cambridge University Press.

${ }^{17}$ The term Kulturnation is very problematic. It was first used to define the community of "Germans" before there was a German nation state, but later also to gloss over the fact that there had never been a democratic political procedure that created the new German Empire. Thus it indicated a minority complex in relation to more democratic states like the USA or France by emphasizing that Germans were more educated ("kultiviert") and thus elevated above the mundane political business (from which most of them were excluded). 
Boisits, B., 2004. Formalismus als österreichische Staatsdoktrin? Zum Kontext musikalischer Formalästhetik innerhalb der zentraleuropäischen Wissenschaft. In: M. Barbo, ed. Muzikološki Zbornik. XL/1-2. Ljubljana: Oddelek za muzikologijo Filozofske fakultete Univerze v Ljubljani. 129-136. Burnham, S., 1995. Beethoven Hero. Princeton: Princeton University Press.

Cepl-Kaufmann, G. and Johanning, A. eds., 2003. Mythos Rhein. Zur Kulturgeschichte eines Stromes, Darmstadt: Wissenschaftliche Buchgesellschaft. Dennis, D. B., 1996. Beethoven in German Politics 1870-1989. New Haven: Yale University Press.

Dittrich, M., 2001. "Jenem imponierenden Heroismus entzogen” - Franz Schubert und das Österreich-Bild nach Königgrätz. In: D. Berke, W. Dürr, W. Litschauer and C. Schumann, eds. Schubert-Jahrbuch 1999. Bericht über den internationalen Schubert-Kongreß. Duisburg 1997. "Franz Schubert-Werk und Rezeption". Part 3: Ästhetik, Rezeption und Methodenfragen. Duisburg: Deutsche Schubert-Gesellschaft, Bärenreiter. 3-21.

Dittrich, M. A., 2007. Evangelist or Socialist: Johann Sebastian Bach in the Cold War and Other Periods of National Uncertainty. In: L. Stefanija and K. Bogunović Hočevar, eds. Muzikološki Zbornik. XLIII/2. Ljubljana: Oddelek za muzikologijo Filozofske fakultete Univerze v Ljubljani. 277-287.

Dittrich, M. A., 2011. "Piefke". Die Inszenierung des Deutschen durch

Militärmusik. In: D. von Redepenning and J. Steinheuer, eds. Inszenierung durch Musik. Der Komponist als Regisseur. Liber amicorum Silke Leopold. Kassel: Bärenreiter. 210-220.

Eggebrecht, H. H., 1991. Musik im Abendland. München: Piper.

Gradenwitz, P., 2000. Wege zum Werk Arnold Schönbergs. Seine Schüler als Lehrer. In: C. Meyer, ed. Bericht zum Symposium "Arnold Schönbergs Wiener Kreis”. Wien, 12-15 September 1999. Wien: Arnold Schönberg Center. 1827.

Grove, G., 1883. Dictionary of Music and Musicians. London: McMillan.

Hegel, G. W. F., 1961. Vorlesungen über die Philosophie der Geschichte. Mit einer Einleitung von Theodor Litt. Stuttgart: Reclam.

Khaynach, F. F. v., 1893. Anton von Werner und die Berliner Hofmalerei. VerlagMagazin, 28.

La Mara (Lipsius, M.), 1868. Musikalische Studienköpfe (Weber, Schubert, Mendelssohn Bartholdy, Schumann, Chopin, Liszt, Wagner). Leipzig: Weißbach. Mayer-Hirzberger, A., 2008. “... ein Volk von alters her musikbegabt”. Der Begriff "Musikland Österreich" im Ständestaat. In: Musikkontext: Studien zur Kultur, Geschichte und Theorie der Musik. 4. Frankfurt am Main: P. Lang.

Neue Zeitschrift für Musik, 1872. "Franz Schubert. Seinem Andenken.” Neue Zeitschrift für Musik, nr. 25, 14 June. 255. 
Potter, P. M., 1998. Most German of the Arts: Musicology and Society from the Weimar Republic to the End of Hitler's Reich. New Haven: Yale University Press. Rufer, J., 1959. Das Werk Arnold Schönbergs. Kassel: Bärenreiter.

Suchy, V., 1965. Grillparzer und der Österreich-Gedanke. In: Institut für Österreichkunde and Bietak, W., eds. Neue Beiträge zum Grillparzer- und Stifter-Bild. Graz: Stiasny. 21-45.

Veit, P.?, 1848. Germania. [painting] Available at: https://de.wikipedia.org/ wiki/Datei:Image_Germania_(painting).jpg [Accessed 31 January 2018].

Veit, P., 1834-36. Germania. [painting] Available at: <https://de.wikipedia.org/ wiki/Germania_(Philipp_Veit) $>$ [Accessed 31 January 2018].

Voss, E., 2005. III. Symphonie in Es-Dur, op. 55, "Sinfonia Eroica”. In: R. Ulm. ed. Sth edition. Die 9 Symphonien Beethovens. Entstehung, Deutung, Wirkung. Kassel: Bärenreiter. 100-123.

Wagner, R., 1873. Gesammelte Schriften und Dichtungen. Vol. 9. Leipzig: Fritzsch.

Wette, W., 2008. Militarismus in Deutschland. Geschichte einer kriegerischen Kultur. Frankfurt am Main: Fischer. 